\title{
TRIP ADVISOR AS A TOOL FOR TOURISTS' PREFERENCES ANALYSIS: THE CASE OF MONASTERIES AT FRUŠKA GORA MOUNTAIN, SERBIA
}

\author{
Nataša Dragović ${ }^{21}$ \\ Igor Stamenković ${ }^{22}$ \\ Đorđije Vasiljević ${ }^{23}$
}

\begin{abstract}
Most of the information is now available online, so tourists search different websites that can help them to choose destination, and also which activities to conduct and which places to visit at the destination. Tourists' comments are one of the tools to realise not only good and bad sides of destinations, but also to have insight in all attractions and activities within destinations. One very efficient tool for getting travel advices is an American travel and restaurant website - TripAdvisor, which shows hotel and restaurant reviews, accommodation bookings and other travel-related content. This interactive travel forum is the largest "social travel website" in the world, with about 315 million reviewers (active and inactive) and about 500 million reviews of hotels, restaurants, attractions and other travel-related businesses.

The task of this study is to use TripAdvisor as a tool to gain information about tourists' opinion on their visit to Monasteries of Fruška Gora Mountain in North Serbia. There are 19 monasteries, built in the period from the 15th to the 18th century and aside of natural assets of this mountain, they represent valuable attractions which is why this destination is also named "Holy Mountain" or "Serbian Atos". The contemporary trend in tourism is that people visit holy places which is why type of tourism where people travel individually or in groups for pilgrimage, missionary, or leisure (fellowship) purposes is now defined as religious tourism.

This study will analyse all the comments and reviews of study area sites (monasteries) and present the global opinion on the visitors' choice and preferences according to their travel and social characteristics.
\end{abstract}

Key words: Trip Advisor, Fruška Gora, monastery, religious tourism

\footnotetext{
${ }^{21} \mathrm{PhD}$ student at Department of Geography, Tourism and Hotel management, Faculty of Sciences, University of Novi Sad, Trg Dositeja Obradovića 3, 21000 Novi Sad, Serbia; Corresponding author: dgt.natasa.dragovic2@student.pmf.uns.ac.rs

${ }^{22}$ Assistant Professor at Department of Geography, Tourism and Hotel management, Faculty of Sciences, University of Novi Sad, Trg Dositeja Obradovića 3, 21000 Novi Sad, Serbia

${ }^{23}$ Assistant Professor at Department of Geography, Tourism and Hotel management, Faculty of Sciences, University of Novi Sad, Trg Dositeja Obradovića 3, 21000 Novi Sad, Serbia
} 


\section{INTRODUCTION}

The great influence of the Internet in the tourism industry has resulted in people increasingly planning online travel, seeking information, suggestions and advice from other people, where to travel, what time of year and how to spend time in certain destinations, what is unavoidable and what should not do (HigginsDesbiolles, 2006; Chua and Banerjee, 2013).

Consumers today have a much better understanding of the marketing tools and activities through which travel arrangements are made and, in most cases, rely on the opinions and experiences of other tourists. Tourists are motivated to share their experiences online because they know it will help others, but they also realize a certain social component of community (Hennig-Thurau et al., 2004; Ho and Dempsey, 2010; Fronzetti-Colladon, Guardabascio and Innarellac, 2019). The exchange of opinions and experiences over the Internet has led to the emergence of electronic word-of-mouth, through the exchange of experiences and information (Cheung and Thadani, 2010; Dumenco, 2010; Canhoto and Kietzmann, 2013). Hennig-Thurau et al. (2004) consider eWoM a much better means of marketing information than traditional word-of-mouth because it acts immediately and has a much broader impact when it comes to the number of people who will see the information or message. What makes eWoM even more attractive is the ability to create your own arrangement based on other people's experiences without the involvement of travel agencies (Shanka et al., 2002; Egresi and Prakash, 2019). A large number of review platforms for travel, hotels, restaurants and destination activities on the Internet can be a problem and support for tourists at the same time. One of the most prominent online platform, which is also a means of transmitting electronic word-of-mouth is TripAdvisor. It was launched in 2000 as a US travelrelated content site and it garnered over 75 million user reviews by 2013 (TripAdvisor, 2013; Chua and Banerjee, 2013).By 2016, the number of reviews had grown to over 320 million, which is justified given that the site's services are free and users are the ones who create content on this platform. This platform could also be described as a travel agent helping to create a personal travel arrangement (Jeacle and Carter, 2011; Fili and Križaj, 2016). This is confirmed by one of the studies conducted by Cong et al. (2014), in which visitors said that they were relying on reviews from other users on TripAdvisor.

The purpose of this research is to use the TripAdvisor platform as a means of gaining information and opinion from tourists regarding their visit to the monasteries of Fruska Gora, which were built between the 15th and 18th centuries and represent one of the most important legacies of the Fruška Gora National Park. The analysis of these reviews will determine the general opinion about the choices and preferences of tourists related to their needs, desires and expectations. Certainly 
there is a downside to online review platforms in the travel industry, as users sometimes exaggerate the good or bad comments related to a product or service. This raises the question of the extent to which travelers can rely on online reviews or the extent to which the information shared online is accurate. In this way, trust is one of the problems of sharing experiences on the Internet. Because of that, the positive and negative effects of online reviews will be highlighted as well as the limitations of this research.

\section{ELECTRONIC WORD-OF-MOUTH}

Development of modern technologies has a great impact on people, but most in everyday communication. The availability of the internet made it possible for people to communicate online at any time. When it comes to communication, it does not have to mean direct communication with messages, but all other content created by users. This content in tourism includes all information, experiences, opinions, tips, etc. that users share with others. Previously, such content could be shared as word-of-mouth, and in the last few years the Internet has been a mediator in this communication. Accordingly, a new way of messaging in the travel industry between travelers has emerged - electronic Word-of-Mouth (eWoM).

There are many definitions of eWOM, and Hennig-Thurau et al. (2004) have provided one that simply explains this contemporary phenomenon:

"Any positive or negative statement made by a potential, anctual, or former customer about a product or company that is made available to a multitude of people and institutions through the Internet."

The importance of electronic word-of-mouth is increasing as more and more forms of content spread on the Internet. As the importance is greater, so is the impact that eWom exerts on all Internet users, be they companies, destinations, tourists or someone else (John E. Hogan, Katherine N. Lemon et al., 2005; Michael Trusov, Randolph E. Bucklin et al., 2009; René Algesheimer, Utpal M. Dholakia et al., 2005; John A. Deighton, Leora Kornfeld, 2007; Leivadiotou and Markopoulos, 2010).

When it comes to the degree of trust in eWOM, there are some factors that can further influence trust in online reviews, e.g. if it is something of greater value, the buyer may at the beginning think that he will not be paid or will not receive adequate value for that price. Online reviews can then help make the buyer more confident in their choices, but they can also have a negative impact and create even more concern for the customer (Martin Evans, Ahmad Jamal et al., 2009; Leivadiotou and Markopoulos, 2010). Considering that services are intangible in the tourism industry, the customer cannot know in advance whether his choice based on 
online reviews is good or not until he arrives at the destination (Lewis and Chambers, 2000; Leivadiotou and Markopoulos, 2010). For this reason, the tourism industry carries some risk when it comes to using online reviews as a means of assisting the decision-making process.

The difference between wom and eWom is in geographical space, time and social factor. Also, eWOM can transmit messages in three formats: text, audio and video. There is a much higher number of people who view online content (Gruen, Osmonbekov, \& Czaplewski, 2005; Fili and Križaj, 2016).

Although TripAdvisor has certain downsides, as it happens that users intentionally write good or bad reviews, thus increasing or diminishing the reputation of destinations, hotels and restaurants, it is one of the indispensable tools for organizing travel.

\section{Trip Advisor}

In the literature, scholars have extensively engaged in research on the digital technologies and the tourism industry, so Baka (2016) uses the term "Travel 2.0" for online self-organized travel platforms, referring to Web 2.0 but through its application in tourism. These types of travel arrangements support the decisionmaking process of travelers, which Zhao et al. (2015) represent as an indispensable part of the tourism decision-making process, when tourists seek information regarding destinations, flights, accommodations, restaurants and other useful information related to a particular trip.

Online platforms where users post travel information are not only useful before the trip, but also during their stay at the destination. Tourists often seek additional information through the aforementioned platforms while at their destination, thus completing their own travel experience (Yoo et al., 2016; Nicoli and Papadopoulou, 2017).

As the sharing of travel information on the Internet has reached a high level, some terms have emerged from scholars, such as the virtual tourist community and the digital nomad, which denotes people traveling and creating online content while traveling, such as is e.g. blogging (Wang et al., 2002; Wasserman, 2014; Nicoli and Papadopoulou, 2017).

There are a number of online platforms that help travelers organize their travel, with the biggest success being the TripAdvisor platform. Founded in 2000, based in Newton, Massachusetts, TripAdvisor is one of the leading online decision support platforms for tourists during travel planning. Based on a survey conducted in 2016, this site monthly visits 350 million users and generates 320 million reviews and reviews for 6.2 million hotels, restaurants and attractions at destinations (TripAdvisor, 2016; Fili and Križaj, 2016). 
This online platform allows travelers and customers to share opinions, tips and information regarding destinations, hotels, restaurants, destinations. It also provides birthing to websites for booking flights, accommodations and other activities while traveling. The TripAdvisor platform was successful, as evidenced by a survey conducted in the UK in which $83 \%$ of respondents confirmed that they would always book accommodation if they had a "Traveler's Choice" recommendation (Morris, 2016; Nicoli and Papadopoulou, 2017).

A regression analysis of a hotel in Rome resulted in a "one point increase on the converted 1-10 average review score across online platforms associated with an increase in occupancy rate of 7.5 percentage points" (Viglia, 2016, p. 2045).

According to a 2016 survey, over 212,000 hotels, about 30,000 destinations and 74,000 attractions were reviewed on TripAdvisor (Yoo et al., 2016; Nicoli and Papadopoulou, 2017). It is represented in over 30 countries worldwide, while in China this platform is under website www.daodao.com (TripAdvisor, 2015). This platform also has a Business component, through which it is proven to influence the traveler in the decision-making process. The advantage of using online platforms like TripAdvisor over traditional ways of organizing travel is that users not only create their own travel plan, but influence and help other users / travelers with their comments and reviews. In this way, the flow of information about destinations, attractions, hotels and restaurants is much faster and has a stronger impact on travelers (Munoz-Leiva et al., 2012; Nicoli and Papadopoulou, 2017).

Since travelers share different experiences, both positive and negative, e.g. the hotel can respond to the comment by thanking or explaining the reason for the traveler's bad experience. Thus, hotel consultants are emerging, such as Fritsch and Sigmund (2013), who advise and assist hotels in how to respond to comments, to preserve their reputation (Nicoli and Papadopoulou, 2017).

The media are also involved in new trends in the tourism market, so they follow the newspapers as well as negative reviews on online platforms where users create content. Filoon (2016) highlights the case of a Michelin-starred restaurant in the UK, with a customer complaining about small portions of food, while Fritsch and Sigmund (2013) refer to "trigger happy" those customers who share bad reviews the moment you notice something bad, although that problem may be resolved if you contact the staff.

\section{METHODOLOGY}

The data for this survey were taken from the TripAdvisor website. Comments were manually collected from June 10-30, 2019. The number of comments by attraction was not big, so there was no need to use special data collection software. In order to determine to what extent and in what way the reviews can help visitors to the 
monasteries in Fruska Gora, a descriptive analysis was performed, listing the words that are most used and comments explaining the experiences of visitors. For the city of Novi Sad within the "Activities" card there are reviews for monasteries. Reviews were analyzed separately for each monastery, which the TripAdvisor recognizes. TripAdvisor reviews are written in multiple languages. For the sake of clarity, the comments, which are in another language, have been translated into English. For each comment quoted, the original language in parentheses is written as it appears on the TripAdvisor website. Although the emphasis is on reviews and their analysis, the monasteries for which the reviews have been analyzed will be briefly presented in the section below.

An interactive map has been created on the www.fruskac.net website, showing the heritage of Fruška Gora, including monasteries representing the historical heritage (Picture 1). The map shows all 35 monasteries in the entire territory of Fruska Gora, but TripAdvisor does not recognize all 35 monasteries. As mentioned in the description of the methodology, the analysis covers 10 monasteries.

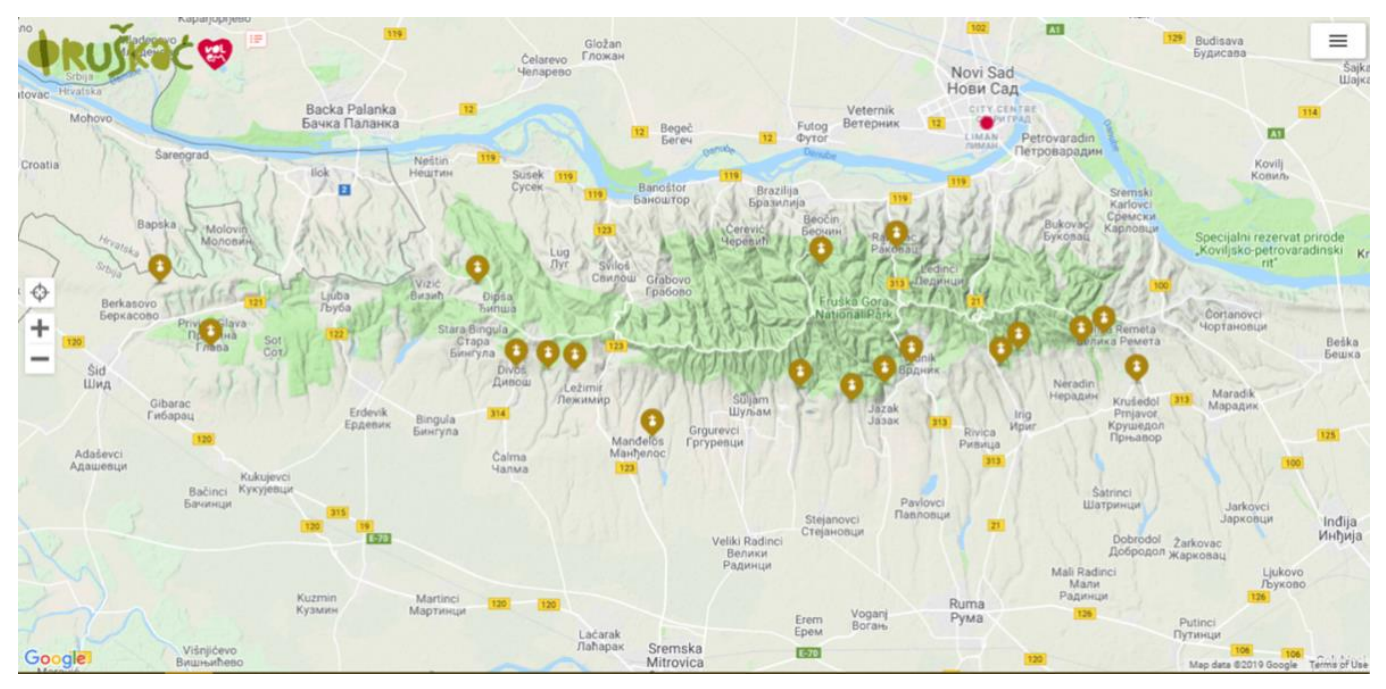

Fig. 1. Interactive map of Fruška Gora - monasteries (www.fruskac.net)

According to information from the official website of the Fruska Gora National Park, a group of monasteries in this territory was built in the period from the 15th to the 18th century. A total of 35 monasteries have been built, and today it is in operation 15. Given the importance of these religious sites, UNESCO protected the monasteries as a cultural and historical heritage. The monasteries were created at a time when the Serbs were trying to resist the Turkish Empire and to represent the faith of that people. Today, monks and nuns maintain active monasteries: Krušedol, Petkovica, Rakovac, Velika Remeta, Divša, Novo Hopovo, Staro Hopovo, Jazak, 
Mala Remeta, Grgeteg, Beočin, Privina Glava, Šišatovac, Kuvežedin and VrdnikRavanica. As for every historical moment, there are also legends about the erection of these monasteries that they nevertheless arose from the 12th to the 15th centuries. What is authentic is the proximity of the monasteries, so visitors often visit more than one monastery at a time, not just one. The period of these monasteries is related to the migration of Serbs and to the famous despotic Brankovic family, modeled on Nemanjić family and their dynasty. Also, the relics of the saints, which are a symbol of the Orthodox faith, are kept in each monastery (www.fruskagora.com).

\section{RESULTS}

Visitors to the Jazak Monastery made mostly positive comments, referring to the peace they experienced during the visit, describing the place in different ways, "peaceful", "a lot of tranquility", "tranquility in everything", "an oasis of peace", "peace". They are also amazed at the beauty of this monastery and its surroundings and therefore most used the words: impressive, beautiful, beauty, kindness, amazing views. Given that the environment was described as very nice, many comments contained the words "well-groomed" and "well-preserved."

Visitors comments are generally full of positive impressions, such as "We enjoyed our visit very much; it is a very pretty monastery and very well preserved...", "A monastery in the middle of the greenery of a park and a lot of tranquility with a church with very old frescos..."(Italian), and some also shared significant information regarding decent dress during a visit to the monastery, "Come properly dressed! Due to hiking shorts I was admitted to the courtyard only (no church)." Visitors belonged to the groups: Families, Couples, Solo, Work, Friends, which means that this monastery attracts a lot of attention from tourists, no matter what the purpose of their trip and who they travel with.

Based on comments from visitors to Grgeteg Monastery, it is possible to conclude that they are delighted with the monastery and its surroundings. Comments include terms like "wonderful", "for every recommendation", "amazing", "mental relaxation", "impressive, imposing, preserved", "beautiful flowerdbeds", "calming landscape", "ancient, medieval", "worth a visit ","very cozy, quiet, blessed place","beautiful and well-groomed area","all in flowers, very clean". Visitors are delighted with the interior of the monastery and the homemade wine and honey, as evidenced by the comments: "...church shop, they make honey... "(Russian)," ...The frescoes are most impressive as the in-house wine-shop selling local wines and 
agricultural products from the monasterial estate","...Monastery's honey is deliciuos and very cheap...","...The frescoes are most impressive as they are in-house wine shops selling local wines and agricultural products from the monasterial estate."

In addition to the nice comments visitors have made about this monastery, there are some tips that can make it easier for those who want to visit the monastery. They mostly recommend going with your own car, as they state in the comments "in a rented car" or "no car without", while some recommend that you reach the monastery via a hiking trail, "...And walking from here to Velika Remeta is amazing! (follow the red trail)","...The monastery can also be reached by a hiking trail that runs throughout Fruska Gora..."According to the website, various groups of tourists visited this monastery: Families, Couples, Solo, Work, Friends.

Similar to the previous, the Petkovac Monastery was described by visitors as "beautiful", which is mentioned in several comments, then "...well-groomed territory gives peace...", "Peaceful, Amazing Place!", "...Offers calm, peace and tranquillity...","...A serene place..."

Visitors also enjoy and highlight the home-made products of the monastery, such as wine, brandy and homemade food that they tried in the dining room. Some of the comments are: "...Nicely located with a small souvenir shop selling homemade ointments, wine and schnapps" (German), "...The monastery's dining room offers locally made brandy and national dishes" (Russian).

Visitors suggest taking a taxi: "...Feel free to take a taxi, just pre-negotiate the price." (Russian), and advise which monasteries it is possible to visit by the way: "...There is parking nearby, you can get either from the side of Šišatovac (we drove from this side, the road was laid normal), or from Divsa" (Russian).Petkovac Monastery is visited by different types of travelers: Families, Couples, Solo, Work, Friends.

There are few comments on Rakovac Monastery, but visitors are generally satisfied with the visit. They shared some information regarding transportation: "...It is only a small number of bus trips and needs to be planned. Photographs are not allowed in the monastery area, but you can take pictures of the hill behind the monastery. There is no signal on the phone near that"(Chinese),"It is close to Novi Sad, easy to reach and worth seeing","10 km from Novi Sad is this Orthodox monastery...Appropriate clothing required when visiting"(Russian) as well as tips on taking photos and dressing. Good reviews are evidenced by the reviews: "This place is a fantastic place to visit. This is a mixed history, religion and past...", "The monastery itself is worth to see, as it has an interesting concept and a very cute small church inside the complex..." 
Velika Remeta Monastery is, according to reviews, a very nice place, many comments contain nice adjectives for the environment, kindness of nuns such as "charming", "isolated and silent", "clean and genuine acceptance", "nice and hospitable", "beautiful architecture ","a stunning impression","astonish place","unforgettable monastery","beautiful scenery","indescribable atmosphere","the monks and nuns are exquisite","so beautiful and original", etc.Similar to other monasteries, it is also possible to buy local produce, brandy, honey, wine, souvenirs, as visitors wrote in their reviews: "they make great brandy, their honey is phenomenal...there is a huge dining room with free and very tasty food..."(English),"Priests next to the monastery sell wine from nearby vineyards, honey and souvenirs"(Polish),"We bought wine and honey..."(Russian),"Very beautiful and old monastery which sells great honey from beekeepers - monks, and you can also buy wine and brandy."The travel type of these visitors was different: Families, Couples, Solo, Work, Friends.

According to small comments, visitors described the monastery Šišatovac as "medieval" and "ancient". They are fascinated by the size of the monastery, but not so much by its appearance inside and out, nor by the fact that they did not meet anyone at that moment, as one visitor points out, "We have been to this Monastery and we have not met a living soul, quite impressive seen from the outside, rather disappointing the interiors especially when compared to those of other monasteries in Fruska Gora" (Italian).

However, there are those who have made positive impressions in every sense, such as, "...It looks very magnificent. The surrounding landscapes amaze with their beauty..." (Russian). This monastery was visited by families, couples and friends.

Visitors to the Privina Glava Monastery mostly came solo or with friends. Comments contain positive impressions, as one user wrote, "...Majestic architecture, a beautiful area around. From every stone around, antiquity blows. I am very glad that I was here." (Russian), but also shared information regarding transportation, "The best form of transport to visit this monastery is a taxi. And it comes out inexpensively, and the driver will give you a ride where you need to (you won't stray and look for an entrance)..."(Russian).

The authenticity of this monastery is also described in the comment of one user, "...Because of Father Gabriel, it is extremely visited because it is known among people that Father Gabriel has supernatural powers and heals the sick" (Serbian).

Some users also shared historical information, "...According to legend, the monastery was founded in 12 century by a man named Privin, but the earliest historical records about the monastery date back to 1566-1567" (Russian) and "This 
old monastery is located on Fruška Gora. It was founded in the 12th century..." (Russian).

The interior of Divsa Monastery made a positive impression based on user reviews. For example user commented, "...The frescoes in the church are interesting, and they have been restored, with bright colors and a more modern style. We regret that we could not find out more about them" (Serbian). Other users also commented on the interior of the monastery and its surroundings, "...The ancient architecture and interior made a strong impression. Pleased with the eye and territory" (Russian) and "...Ancient murals and icons made a special impression on us" (Russian).Visitors came solo, with family or friends.

Few comments on the monastery of Kuveždin, but from the reviews it can be concluded that they are positive impressions, so the user commented, "I highly recommend visiting this monastery. Inside and around, everything breathes the history of old...The most convenient form of transport from the city center is a taxi. It is inexpensive here"(Russian), thereby sharing the transportation information. Another user suggested a way of dressing during the visit, "...Plastic baskets with headscarves and skirts were placed in the port of the monastery so that visitors could enter the church dressed in Christian custom" (English). Users traveled solo or with friends.

Also a small number of comments about the monastery Mala Remeta, but with good impressions from visitors. One user commented, "...it is a well-hidden and very beautiful monastery, both inside and out, accompanied by an old and austere monk, while an old dog kept his guard, suggestive" (Italian).Others commented on the surroundings of the monastery, "...The monastery is a small building with a bell tower, standing a few meters from it. Today, the monastery is completely renovated. We liked the orchards and vineyards on the site" (Russian) and also one user commented,"...Everything has been renovated and looks wonderful, and on the hills surrounding the monastery we have fruit orchards and vineyards..." (Polish). Another user commented on the location and history of the monastery, "This nunnery is located in the southern part of Fruska Mountain. It was founded by King Dragutin and the main church dedicated to the cover of Blessed Virgin Mary." (Russian)The monastery was visited by couples and friends.

\section{DISCUSSION}

For most monasteries the reviews were positive. There are many reviews regarding the appearance of the monastery as well as the interior. Mostly fascinated by 
frescoes and iconostasis in monasteries, but there were also negative comments, e.g. for the interior of the Šišatovac monastery, when a visitor compared this monastery with others in the surroundings that he thought had a really beautiful interior. The environment or nature has made a special impression on the visitors. They emphasized the maintenance of the courtyard and surroundings of the monastery, and therefore praised the monks and nuns, and their dedicated work in the preservation and protection of the courtyard. The fact that they strive for landscaping surrounding the monastery is certainly important, especially for those visitors who come to sleep in the holy place.

The hospitality was also emphasized by the visitors and the way they were received when they came to visit. They could talk to the monks and nuns, they were served food to eat lunch or dinner. They could hear stories about the creation of a monastery, history or some other interesting facts. This suggests that people still seek direct contact while traveling and that this approach leaves a positive and lasting impression.

Tourists love the authenticity of the destinations, especially when they can bring home something that represents a particular region or country. In this case, the monasteries produce local honey, brandy and wine. Most users say they have tried home-made produce, while some have bought and brought home because they were delighted with the flavors.

Access to monasteries is one of the more important factors, according to the reviews analyzed. In most cases, visitors emphasized that it was best to come with their own transportation. The reason for this is the ability to visit more monasteries during one trip. There were also those who, as they say in the reviews, came with taxis for a good price. Since Fruska Gora is a national park often visited by mountaineers, some have advised that it is possible to reach certain monasteries via a footpath, such as the red trail to the Velika Remeta Monastery.

\section{CONCLUSION}

Based on the analysis of the comments, it is possible to conclude that the visitors pay the most attention to the accessibility of the attraction and signaling, how to get to the location (taxi, bus, car, hiking, motorbike), then the environment given that it is a National Park, the way they were welcomed. additional values such as local products, and to a minimum, visitors comment on the history and creation of the monastery, enjoying the peaceful and natural surroundings. The advantage is certainly the proximity of several monasteries and the ability to visit most of Fruska Gora. Almost none of the comments contained information on the distance of the accommodation and additional activities, which justifies religious tourism, beacuse main objective is to visit religious sites and to spend some time there. 
There is often controversy about the relevance of online reviews, as it happens that users intentionally write good or bad comments. Considering that the subject of the research is monasteries or religious sites that tourists do not visit for order, but because they are really interested in the history of the Serbian people, for pilgrimage, missionary or leisure purposes, the possibility that users intentionally wrote good or bad reviews was probably not great. In this way, the intentional comment factor was avoided to some extent.

Although all comments were carefully and thoroughly analyzed, there are some limitations to this research. First of all, there is a difference between the number of comments of individual monasteries. Then, users write reviews when they remember or when they have internet access, and thus their impressions change slightly. In this study, it was not analyzed when the reviews, ie. how much time after the visit and to what extent it could affect the split review. There is information on TripAdvisor about when a user visited a destination and when they wrote a review. In future research, this factor will be taken into account in order to complement the analysis of online reviews.

Online reviews are to some extent helpful to other users and tourists alike, because they can find tips, important information, but of course the experience of such holy places is individual, it causes different feelings for people. Therefore, a distinction should be made between a place that has a certain emotion in people and a place like a hotel where a good accommodation and food should be provided to the guest. In the decision-making process, reviews from TripAdvisor can be a helpful tool for travelers when planning their trip, but they should not be relied on completely. Other forms of information may be additional tools to support the decision-making process during travel planning.

\section{ACKNOWLEDGEMENTS}

This research was supported by the Ministry of Education, Science, and Technological Development of Republic of Serbia (Grant No. 176020).

\section{REFERENCES}

1. Algesheimer, R., Dholakia, U.M., Herrmann, A. (2005). The Social Influence of Brand Community: Evidence from European Car Clubs. Journal of Marketing, Volume 69, 19-34.

2. Baka, V. (2016). The becoming of user-generated reviews: looking at the past to understand the future of managing reputation in the travel sector. Tourism Management, Volume 53, 148-162. 
3. Canhoto, A.I., Kietzmann, J. (2013). Bitter-Sweet! Understanding and Managing Electronic Word of Mouth. Journal of Public Affairs, Volume 13(2), 146-159. DOI: $10.1002 / \mathrm{pa} .1470$

4. Cheung, C.M.K., Thadani, D.R. (2010). Proceedings from PACIS 2010: Pacific Asia Conference on Information Systems. Taipei, Taiwan.

5. Chua, A.Y.K., Banerjee, S. (2013). Proceedings from the World Congress on Engineering and Computer Science 2013. San Francisco, USA.

6. Colladon, A.F., Guardabascio, B., Innarella, R. (2019). Using social network and semantic analysis to analyze online travel forums and forecast tourism demand. Decision Support Systems 123.

7. Cong, L., Wu, B., Morrison, A.M., Shu, H., Wang, M. (2014). Analysis of wildlife tourism experiences with endangered species: An exploratory study of encounters with giant pandas in Chengdu, China. Tourism Management, Volume 40, 300-310.

8. Deighton, J., Kornfeld, L. (2009). Interactivity's Unanticipated Consequences for Marketers and Marketing. Journal of Interactive Marketing, Volume 23(1), 4-10. DOI: 10.1016/j.intmar.2008.10.001 DOI: $10.2139 /$ ssrn. 1129351

9. Dumenco, S. (2010, January). Be honest: what's your real Twitter and Facebook ROI? AdAge. Retrieved from https://adage.com/article/themedia-guy/social-media-real-twitter-facebook-roi/141381

10. Egresi, I., Prakash, T.G.S.L. (2019). What makes wildlife tourists happy and what disappoints them? Learning from reviews posted on TripAdvisor. GeoJournal of Tourism and Geosites, Volume 24(1), 102-117.

11. Evans, M.M., Foxall, G., Jamal, A. (2009). Consumer Behaviour 2nd Edition. Hoboken, New Jersey, USA: Wiley.

12. Fili, M., Križaj, D. (2016). Electronic Word of Mouth and Its Credibility in Tourism: The Case of Tripadvisor. Academica Turistica, Volume 9(2), 107111.

13. Filoon, W. (2016, February). Michelin-starred chef bites back at disgruntled TripAdvisor reviewer. Eater.

14. Fritsch, A., Sigmund, H. (2013). Managing hotel reviews. Stuttgart: Matthaes Verlag GmbH.

15. Gruen, T.W., Osmonbekov, T., Czaplewski, A.J. (2005). Ewom: The impact of customer-to-customer online know-how exchange on customer valure and loyalty. Journal of Business Research, Volume 59(4), 449-456.

16. Hennig-Thurau, T., Gwinner, K.P., Walsh, G., Gremler, D.D. (2004). Electronic word-of-mouth via consumer-opinion platforms: what motivates consumers to articulate themselves on the internet? Journal of Interactive Marketing, Volume 18, 38-52. 
17. Higgins-Desbiolles, F. (2006). More than an "industry": The forgotten power of tourism as a social force. Tourism Management, Volume 27(6), 1192-1208.

18. Ho, J.Y.C., Dempsey, M. (2010). Viral marketing: motivations to forward online content. Journal of Business Research, Volume 63, 1000-1006.

19. Hogan, J.E., Lemon, K.N., Libai, B. (2005). Quantifying the Ripple: Wordof-Mouth and Advertising Effectiveness. Journal of Advertising Research, Volume 44(03). DOI: 10.1017/S0021849904040243

20. http://www.fruska-gora.com/

21. http://www.tripadvisor.com/PressCenter-c4-FactSheet.html

22. https://fruskac.net/

23. https://tripadvisor.mediaroom.com/us-about-us

24. https://www.tripadvisor.com/PressCenter-c6-About_Us.html

25. Jeacle, I., Carter, C. (2011). In TripAdvisor we trust: Rankings, calculative regimes and abstract systems. Accounting, Organizations and Society, Volume 36(4/5), 293-309.

26. Leivadiotou, E., Markopoulos, D. (2010). Proceedings from MIBES 2010: Management of International Business and Economics Systems. Kavala, Greece.

27. Lewis, R., Chambers, R. (2000). Marketing leadership in hospitality: Foundations and practices. New York: John Wiley \& Sons.

28. Morris, H. (2016, February). Trip advisor criticised after closed Tunisian terror hotel given top award. The Telegraph. Retrieved from https://www.telegraph.co.uk/travel/news/tripadvisor-under-fire-over-awardfor-tunisian-hotel/

29. Munoz-Leiva, F., Hernandez-Mendez, J., Sanchez-Fernandez, J. (2012). Generalizing user behaviour in online travel sites through the Travel 2.0 website acceptance model. Online Information Review, Volume 36(6), 879902.

30. Nicoli, N., Papadopoulou, E. (2017). TripAdvisor and reputation: a case study of the hotel industry in Cyprus. EuroMed Journal of Business, Volume 12(3), 316-334.

Retrieved from https://mashable.com/2014/11/09/digital-nomads/

Retrieved from www.eater.com/2016/2/8/10936906/tripadvisor-purnellsreview-fight

31. Shanka, T., Ali-Knight, J., Pope, J. (2002). Intrastate travel experiences of international students and their perceptions of Western Australia as a tourist destination. Tourism and Hospitality Research, Volum 3(3), 245-256. 
32. Trusov, M., Bucklin, R.E., Pauwels, K. (2008). Effects of Word-of-Mouth Versus Traditional Marketing: Findings from an Internet Social Networking Site. Journal of Marketing, Volume 73(5), 90-102.

33. Viglia, G., Minazzi, R., Buhalis, D. (2016). The Influence of e-word-ofmouth on hotel occupancy rate. International Journal of Contemporary Hospitality Management, Volume 28(9), 2035-2051.

34. Wang, Y., Yu, Q., Fesenmaier, D.R. (2002). Defining the virtual tourist community: implications for tourism marketing. Tourism Management, Volume 23(4), 407-417.

35. Wasserman, T. (2014, November). Digital nomads travel the world while you rot in your office. Mashable.

36. Yoo, K.H., Sigala, M., Gretzel, U. (2016). Exploring tourism. New York: Springer.

37. Zhao, X., Wang, L., Guo, X., Law, R. (2015). The influence of online reviews to online hotel booking intentions. International Journal of Contemporary Hospitality Management, Volume 27(6), 1343-1364. 